\title{
Importance, Destruction and Recovery of Coral Reefs
}

\author{
- Leonie Sophia van den Hoek, ${ }^{2)}$ Emad K. Bayoumi \\ Department of Marine Biology Science, Liberty International University, Wilmington, USA \\ Department of General Surgery, Medical Academy Named after S. I. Georgiesky of Crimea Federal University, \\ Crimea, Russia
}

\begin{abstract}
Coral reefs are an incredibly valuable ecosystem. [2] Coral reefs are being degraded worldwide by several reasons such as; human activities, increases in cyclone intensity, climate warming, bleaching and so on. The increasing frequency and severity of anthropogenic impacts throughout the global ocean have an impact on the coral reefs. This worldwide decline of coral reefs calls for an urgent reassessment of current management practices [1]. Coral reefs are important for our world for several reasons. Besides the fact that they are very beautiful and attract tourists, thus they function as a very important income, and they have other benefits for our marine environment and world such as symbioses and a source to finding medicine. In this review we point out the importance, destruction and the recovery of coral. \%. Healthy Corals are one of the most valuable ecosystems on earth, the provide a huge income in environmental and economic services, such as coastal protection, tourism and food. Techniques to restore the coral reefs impacted by human disturbance are; salvaging sponges and corals, removing loose debris from the reef, rebuilding three-dimensional (3-D) structures onto leveled-scarified reef surfaces, and transplanting sponges and corals back on the cleared reef surfaces. [36]
\end{abstract}

Keywords: marine ecosystems, coral reefs, symbioses, biodiversity,

\section{Introduction}

Coral reefs are being degraded worldwide by several reasons such as; human activities, increases in cyclone intensity, climate warming, bleaching and so on. The increasing frequency and severity of anthropogenic impacts throughout the global ocean have an impact on the coral reefs. This worldwide decline of coral reefs calls for an urgent reassessment of current management practices [1]. Coral reefs are an incredibly valuable ecosystem. [2] They are important for our world for several reasons. Besides the fact that they are very beautiful and attract tourists, thus they function as a very important income, and they have other benefits for our marine environment and world such as symbioses and a source to finding medicine.

Corals fall under the phylum Cnidaria and the class Anthozoa. Corals are related to jellyfish and anemones. They constitute along with sea anemones, jellyfish, and hydras, the oldest eumetazoan phylum [3]. When free-swimming coral larvae (planulae) attach to the submerged edges of islands or continents, coral reefs begin to form. Such as: scleractinians, which are colonial organisms composed of hundreds to hundreds of thousands of individuals, called polyps [4]. According to the NOAA, the National Oceanic and Atmospheric Administration (U.S department of Commerce), Coral reefs take on one of three major characteristic structures while they are growing and expanding. This can be; fringing, barrier or atoll. All three reef types share similarities in their biogeographic profiles. Bottom topography, depth, wave and current strength, light, temperature, and suspended sediments all act to create characteristic horizontal and vertical zones of corals, algae and other species. While these zones vary per the location and type of reef, the major divisions common to most reefs, as they move seaward from the shore, are the reef flat, reef crest or algal ridge, buttress zone, and seaward slope (NOAA).

Coral reefs are mostly famous because of their beauty which attracts tourism. Many people love to swim and float over the coral reefs and enjoy the many colours and magnificent shapes and diversity they show. This review article is to point out the importance of corals for the oceanic ecosystems, the destruction of these corals and what we can learn from them and then the recovery of coral reefs. According to NOAA, approximately 500 million people worldwide depend upon reefs for food and their livelihoods, and 30 million are almost totally dependent upon reefs. The coral reefs are supporting people whose lives depend on these natural resources for a source of food and income [2]. Over 39\% of the world population now live within 100 kilometres of the coast and many people in these areas depend on reefs [2].

The ocean encompasses almost three quarters of the surface of the earth, we live on the "blue planet" according poet James Dickey after seeing the photos of the Apollo mission in1968. The oceans encompass $70.78 \%$ of the top layer of the earth, on top of the lithosphere [5]. The Coral reefs cover $<0.1 \%$ of the global ocean surface area, yet, they host over a quarter of all known fish species on Earth and the vertebrate species' density (number of species per unit area) is far greater than that of rain forest [6]. They host almost a quarter of 
all known fish species on earth, which is almost $25 \%$. Healthy Corals are one of the most valuable ecosystems on earth, the provide a huge income in environmental and economic services, such as coastal protection, tourism and food.

\section{Importance and Contraindications}

Coral reefs are important for our world for several reasons. Besides the fact that they are very beautiful and attract tourists, thus they function as an very important income, and they have other benefits for our marine environment and world. For example: Corals provide paleoclimatic information on the behaviour of the tropical oceans that is available from no other proxy. [7] Corals incorporate geochemical tracers of climate that are relatively simple to measure to produce high-quality climate records. They also allow accurate dating by several means. The Records may span centuries at monthly to annual resolution, or corals may provide shorter highresolution windows into the deeper past. In the tropical Pacific and Indian Oceans, there is now a collection of c. 20 records available [7].

According to the The National Coral Reef Monitoring Program (NCRMP), When coral reefs are threatened by climate change, unsustainable consumption, and land-based pollution, nearby communities and cultures are also at risk. Estimates in this report [2] show that coral reefs provide each year nearly 30 billion US dollar, in net benefits, in goods and services to world economies, including; tourism, fisheries and coastal protection.

Across 157 sites in Seychelles, Maldives, the Chagos Archipelago, and Australia's Great Barrier Reef, They [8] find that structural complexity and reef zone are the strongest and most consistent predictors of reef fish abundance, biomass, species richness, and trophic structure. They estimate that there may be another 1 to 8 million undiscovered species of organisms living in and around reefs [9]. This biodiversity is very important because it is, among other things, a key to finding medicine that are now being developed from coral reef animals and plants as possible cures for cancer, arthritis, human bacterial infections, viruses, and other diseases.

With the ongoing decrease of coral reefs, understanding the links between coral habitat and reef fishes is of critical importance. As example, after the 1982-1983 El Niño in 1983 About 70\% of the carols reefs died in the areas of the east Pacific Ocean and in the Caribbean Sea, caused by bleaching. It took several years for most of the coral reefs to recover. In the next part there is more about the destruction of coral reefs, just the question now is, what are we actually losing? The findings in a research [8] highlight that reef complexity relies on living corals - with different traits and life histories - continuing to build carbonate skeletons, and that these nuanced relationships between coral assemblages and habitat complexity can affect the structure of reef fish assemblages.

Coral reefs have a relation with many species. For example, the coral reefs and sharks. Sharks are considered the apex predator of coral reefs. In another review [10] they find that most reef-associated shark species do not act as apex predators but instead function as mesopredators along with a diverse group of reef fish. Cited: "Coral reefs provide some functional benefits to sharks, but sharks do not appear to favour healthier reef environments. While coral reefs provide a range of ecological benefits for sharks, the link between healthy reefs and shark abundance is unclear. " [10].

In a recent research [11] they found that sharks were significantly more diverse, more abundant, larger in size and greater in biomass in the marine reserve relative to the Scott Reefs. I will cite their findings; 'Our results provide large-scale evidence consistent with the hypothesis that reef-associated sharks are gape-limited trophic omnivores that impose top-down effects on medium sized $(<50 \mathrm{~cm})$, low-to mid-trophic level fishes. On stereo-BRUVS, for example, prey in the 0 to $29.99 \mathrm{~cm}$ size class had 203\% more biomass at the predatordepleted reef relative to the location where sharks were abundant. As body size is an important determinant of ecological role and fitness in fishes, these findings suggest that the rapid and ongoing loss of sharks from reefs globally may have important implications for reef management and investigations into the effect of fishing on reef systems. ", > [11].

However, there is also research [12] in which they found that coral reefs have a negative effect on the biodiversity: In an in situ palatability bioassay the extract of T. tagusensis reduced predation by generalist fish. Their results demonstrate that both coral species have chemical substances which can bring about a negative interaction with potential fish predators and competitors such as algal and invertebrate foulers and the advantage gained could explain their success in invading new regions to the detriment of local fauna and flora [12]. Coral reefs form marine-biodiversity hotspots of enormous ecological, economic, and aesthetic importance that rely energetically on a functional symbiosis between the coral animal and a photosynthetic alga. [13] Such as the relation between coral and marine organism, the Corals depend upon a functional symbiosis between a cnidarian animal host (the coral) and intracellular photosynthetic dinoflagellate algae. [13]

Coral reefs are the most biologically diverse of shallow water marine ecosystems. [14] 


\section{Destruction}

Coral reefs are under heavy pressure. According to [2] is 27\% permanently lost and with current trends, a further $30 \%$ is at risk of being lost in the coming thirty years. Coral reefs are being degraded by several reasons, in one of the researchers that is used for this review they name that Coral reefs are being degraded worldwide by human activities and climate warming [14]. cited: 'Analyses of the geographic ranges of 3235 species of reef fish, corals, snails, and lobsters revealed that between $7.2 \%$ and $53.6 \%$ of each taxon have highly restricted ranges, rendering them vulnerable to extinction. Restricted-range species are clustered into centers of endemism, like those described for terrestrial taxa. The 10 richest centers of endemism cover $15.8 \%$ of the world's coral reefs $(0.012 \%$ of the oceans) but include between 44.8 and $54.2 \%$ of the restricted-range species." They found that in regions where reefs are being severely affected by people, the reefs are leading potentially to numerous extinctions.

Furthermore, the possibility of global warming is named again as a threat for coral reefs and associated organisms, global warming can result in rising sea levels and periods of increased temperature stress, and this may also bring increased storm frequency and intensity. [15] The threat is through fatal heat stress to corals and indirectly, by boosting the energy of cyclones that cause coral destruction and loss of associated organisms [16]. It is said that increases in cyclone intensity predicted for this century are sufficient to greatly accelerate coral reef degradation, this conclusion comes from data from the Australia's Great Barrier Reef [16].

The direct threat of heat in corals is looked at closer in [17]; three common species of Hawaiian reef corals, Pocillopora damicornis (L.), Montipora verrucosa (Lamarck) and Fungia scutaria Lamarck, were grown in a temperature-regulated, continuous-flow sea water system. They found that in prolonged exposure to temperatures of approximately $30^{\circ} \mathrm{C}$, it eventually caused loss of photosynthetic pigment, increased mortality, and reduced calcification, However, they suggest also that ultimately low temperature is more deleterious than high temperature. Their results show that a decrease in the natural water temperature of Hawaiian reefs would be more harmful to corals than a temperature increase of the same magnitude [17].

According to [18] human activity and ecosystem disruption are strongly correlated, regardless of local fish biodiversity. However, they [18] documented changes in ecosystem function on coral reefs at regional biogeographical scales as a result of overfishing of just one species, the giant hump head parrotfish (Bolbometopon muricatum). High coral mortality has also been associated with natural events such as hurricanes, predator outbreaks and periods of high temperature, [15] but they find that high mortality also resulted from excess nutrients in sewage and from specific pollutants. Of particular concern are the consequences of bleaching of large numbers of reef-building scleractinian corals and hydrocorals. [19]

The increasing frequency and severity of anthropogenic impacts throughout the global ocean has led to habitat degradation, fragmentation, and trophic downgrading of marine ecosystems worldwide [20,21]. However, as cited from [22]; 'Large animals declined before small animals and architectural species, and Atlantic reefs declined before reefs in the Red Sea and Australia, but the trajectories of decline were markedly similar worldwide. All reefs were substantially degraded long before outbreaks of coral disease and bleaching. Regardless of these new threats, reefs will not survive without immediate protection from human exploitation over large spatial scales."

As one of the reasons is the acidification they made an expectation for the $21^{\text {st }}$ century; global warming and ocean acidification will compromise carbonate accretion, with corals becoming increasingly rare on reef systems, such as less diverse reef communities and carbonate reef structures that fail to be maintained [23].

\section{Recovery and Complications}

The worldwide decline of coral reefs calls for an urgent reassessment of current management practices [1]. Scaled-up management intervention and decisive action on global emissions and improved understanding of the ecological processes that underlie reef resilience, are required if the loss of coral-dominated ecosystems is to be avoided [23, 1], as cited [1]; 'Managing for improved resilience, incorporating the role of human activity in shaping ecosystems, provides a basis for coping with uncertainty, future changes and ecological surprises."

According to [24] needs the International integration of management strategies that support reef resilience to be vigorously implemented, and complemented by strong policy decisions to reduce the rate of global warming. Furthermore, Threatened centres of endemism are major biodiversity hotspots, and conservation efforts targeted toward them could help avert the loss of tropical reef biodiversity [14]. Such as the management of a larger seascape-landscape of which human activities are seen as integrated parts is required to help conserving the capacity of reefs to generate essential services [25]. Seascape-level estimates of structural complexity are rapid and cost effective with important implications for the structure and function of fish assemblages, and should be incorporated into monitoring programs. [8]

[16] As said before, recovery in the Australia's Great Barrier Reef, of average coral cover was relatively slow and there were further declines in fish species richness and abundance. But in a different area, the Caribbean coral reefs, after an attempt to quantify the contribution of hurricanes to Caribbean coral, [26] 
they didn't find evidence of recovery to a pre-storm state for at least eight years after impact. The overall lack of post-hurricane recovery points to a general impairment of the regeneration potential of Caribbean coral reefs. [26] A challenge for ecosystem management are the unanticipated impacts of consumers in fragmented habitats. [27] they say that an understanding of predator dynamics as a function of habitat type, size, and fragmentation needs to be incorporated into MPA design and management, because small marine protected areas, can dramatically increase the cover of foundation species like corals, but may selectively attract coral predators like crown-of-thorns sea stars (Acanthaster), due to greater food densities within MPAs or because the small marine protected areas are too small to support Acanthaster enemies. [27]

The ability of coral reefs to survive the projected increases in temperature due to global warming will depend largely on the ability of corals to adapt or acclimatize to increased temperature extremes over the next few decades. [28] As cited: ' While this increase is of huge ecological significance for many coral species, in the absence of other mechanisms of thermal acclimatization/adaptation, it may not be sufficient to survive climate change under predicted sea surface temperature scenarios over the next 100 years. However, it may be enough to 'buy time' while greenhouse reduction measures are put in place." [28]

Another challenge is the successful recruitment of juvenile stony corals, as it is essential for healthy coral reef ecosystems [29], [30]. The challenge here is that when local populations of stony corals are reduced, settlement of new coral recruits is also reduced [31], [32]. Ecological and organismal consequences of increased seawater temperatures have been investigated extensively in reef-building corals ([33], [34], [35]. The complication here is that, cold tolerance of corals spanning tropical and subtropical waters is much less understood. With the frequency of extreme weather episodes, including cold anomalies, predicted to increase under climate change scenarios, a better understanding of the effect of hypothermic stress on stony corals is warranted [36]. According to [36] In a response to chronic reef damage in Florida, federal and state agencies and consultants have developed techniques to restore, reefs impacted by human disturbance. Such as; salvaging sponges and corals, removing loose debris from the reef, rebuilding three-dimensional (3-D) structures onto levelled-scarified reef surfaces, and transplanting sponges and corals back on the cleared reef surfaces.

\section{Conclusion or Discussion}

Coral reefs are a great income for the world [2], they are a key in research for medicine and host a biodiversity that is almost $25 \%$ of all marine species. The global destruction of coral reefs is not only from this century but has happened before by natural sources, however humans have a great impact on the pollutions of the sea and the destruction of coral reefs. This worldwide decline of coral reefs calls for an urgent reassessment of current management practices [1]. According to conclusions of many researchers, the coral reef needs protection, and it needs it now. Coral reefs need more research for the recovery, because natural forces are difficult to control. When we focus on recovery more than prevention, then prevention van also be found in human behaviour, and this is another important issue to be managed by special programs. According to [2] is $27 \%$ permanently lost and with current trends, a further $30 \%$ is at risk of being lost in the coming thirty years. What will happen after those thirty years, will coral go extinct?

\section{References}

[1]. D. R. Bellwood, T. P. Hughes, C. Folke, M. Nyström. (2004), Confronting the coral reef crisis. Nature 429, 827-833. doi:10.1038/nature02691.

[2]. Cesar, H, and Burke, L. and Pet-Soede, L (2003) The Economics of Worldwide Coral Reef Degradation. Technical Report.

[3]. Nicholas H. Putnam1, Mansi Srivastava2, Uffe Hellsten1, Bill Dirks2, Jarrod Chapman1, Asaf Salamov1, Astrid Terry1, Harris Shapiro1, Erika Lindquist1, Vladimir V. Kapitonov3, Jerzy Jurka3, Grigory Genikhovich4, Igor V. Grigoriev1, Susan M. Lucas1, Robert E. Steele5, John R. Finnerty6, Ulrich Technau4, Mark Q. Martindale7, Daniel S. Rokhsar1,2, Science 06 Jul 2007: Vol. 317, Issue 5834, pp. 86-94, DOI: $10.1126 /$ science. 1139158

[4]. Barnes, R.D. 1987. Invertebrate Zoology; Fifth Edition. Fort Worth, TX: Harcourt Brace Jovanovich College Publishers. pp. 92-96, 127-134, 149-162.

[5]. (David W. Townsend, Oceanography and Marine Biology, 2012, ISBN 9780878936021).

[6]. Michel J Kaiser, Martin J Attrill, Simon Jennings, David N Thomas, David K. A. Barnes, Andrew S. Brierley, Jan G. Hiddink, Hermanni Kaartokallio, Nicholas V. C. Polunin, and David G. Raffaelli, Marine Ecology; Processes, Systems, and Impacts, $2^{\text {nd }}$ ed. ISBN 9780199227020

[7]. Cole, J. E. (2014). Holocene coral records: Windows on tropical climate variability. In Global Change in the Holocene (pp. 168184). Taylor and Francis. DOI: $10.4324 / 9780203785027$

[8]. Darling, E.S., Graham, N.A.J., Januchowski-Hartley, F.A. et al. Coral Reefs (2017). doi:10.1007/s00338-017-1539-z

[9]. Cortés, J. Coral Reefs (1997), Biology and geology of eastern Pacific coral reefs, 16(Suppl 1): S39. doi:10.1007/s003380050240

[10]. George Roff, George Roff, George Roff, Christopher Doropoulos, Alice Rogers, Yves-Marie Bozec, Nils C. Krueck, Eleanor Aurellado, Mark Priest, Chico Birrell, Peter J. Mumby, Peter J. Mumby, The Ecological Role of Sharks on Coral Reefs Volume 31, Issue 5, p395-407, May 2016. DOI: http://dx.doi.org/10.1016/j.tree.2016.02.014

[11]. Barley SC, Meekan MG, Meeuwig JJ (2017) Species diversity, abundance, biomass, size and trophic structure of fish on coral reefs in relation to shark abundance. Mar Ecol Prog Ser 565:163-179.

[12]. Bruno G. Lages, Beatriz G. Fleury, Angelo C. Pinto, Joel C. Creed (27 May 2010) Chemical defenses against generalist fish predators and fouling organisms in two invasive ahermatypic corals in the genus Tubastraea DOI: 10.1111/j.14390485.2010.00376.x 
[13]. Sebastian Baumgartena, Oleg Simakovb, Lisl Y. Esherickc, Yi Jin Liewa, Erik M. Lehnertc, Craig T. Michella, Yong Lia, Elizabeth A. Hambletonb, Annika Guseb, Matt E. Oatesd, Julian Goughd, Virginia M. Weise, Manuel Arandaa, John R. Pringlec, and Christian R. Voolstraa, 2015, The genome of Aiptasia, a sea anemone model for coral symbiosis, NCBI database (accession no. PRJNA261862).

[14]. Callum M. Roberts, Colin J. McClean, John E. N. Veron, Julie P. Hawkins, Gerald R. Allen, Don E. McAllister, Cristina G. Mittermeier, Frederick W. Schueler, Mark Spalding, Fred Wells, Carly Vynne, Timothy B. Werner, Marine Biodiversity Hotspots and Conservation Priorities for Tropical Reefs, Science 15 Feb 2002; Vol. 295, Issue 5558, pp. 1280-1284, DOI: $10.1126 /$ science. 1067728 .

[15]. KENNETH P. SEBENS, Biodiversity of Coral Reefs: What are We Losing and Why? Integr Comp Biol (1994) 34 (1): 115-133. Published: 01 August 2015 DOI: https://doi.org/10.1093/icb/34.1.115.

[16]. Cheal, A. J., MacNeil, M. A., Emslie, M. J. and Sweatman, H. (2017), The threat to coral reefs from more intense cyclones under climate change. Glob Change Biol. doi:10.1111/gcb.13593

[17]. Jokiel, P.L. \& Coles, S.L. Mar. Biol. (1977), Effects of temperature on the mortality and growth of Hawaiian reef corals. 43: 201. doi:10.1007/BF00402312

[18]. David R. Bellwood, Andrew S. Hoey, J. Howard Choat, Limited functional redundancy in high diversity systems: resilience and ecosystem function on coral reefs (2003), DOI: 10.1046/j.1461-0248.2003.00432.x

[19]. Glynn, P.W. Coral Reefs (1993) 12: 1. doi:10.1007/BF00303779

[20]. Estes JA, Terborgh J, Brashares JS, Power ME, Berger J, Bond WJ, et al. Trophic downgrading of planet Earth. Science. 2011;333(6040):301-306. doi: 10.1126/science.1205106. pmid:21764740

[21]. McCauley DJ, Pinsky ML, Palumbi SR, Estes JA, Joyce FH, Warner RR. Marine defaunation: animal loss in the global ocean. Science. 2015;347(6219):1255641. doi: 10.1126/science.1255641. pmid:25593191

[22]. John M. Pandolfi, Roger H. Bradbury, Enric Sala, Terence P. Hughes, Karen A. Bjorndal, Richard G. Cooke, Deborah McArdle, Loren McClenachan, Marah J. H. Newman, Gustavo Paredes, Robert R. Warner, Jeremy B. C. Jackson. (2003), Global Trajectories of the Long-Term Decline of Coral Reef Ecosystems. Science, Vol. 301, Issue 5635, pp. 955-958. DOI: 10.1126/science.1085706

[23]. O. Hoegh-Guldberg, P. J. Mumby, A. J. Hooten, R. S. Steneck, P. Greenfield, E. Gomez, C. D. Harvell, P. F. Sale, A. J. Edwards, K. Caldeira, N. Knowlton, C. M. Eakin, R. Iglesias-Prieto, N. Muthiga, R. H. Bradbury, A. Dubi, M. E. Hatziolos. (2007), Coral Reefs Under Rapid Climate Change and Ocean Acidification. Science, Vol. 318, Issue 5857, pp. 1737-1742. DOI: 10.1126/science.1152509

[24]. T. P. Hughes, A. H. Baird, D. R. Bellwood, M. Card, S. R. Connolly, C. Folke, R. Grosberg, O. Hoegh-Guldberg, J. B. C. Jackson, J. Kleypas, J. M. Lough, P. Marshall, M. Nyström, S. R. Palumbi, J. M. Pandolfi, B. Rosen, J. Roughgarden, (2003), Science. Vol. 301, Issue 5635, pp. 929-933. DOI: $10.1126 /$ science. 1085046

[25]. Fredrik Moberga, Carl Folkea, Ecological goods and services of coral reef ecosystems, Ecological Economics; Volume 29, Issue 2, May 1999, Pages 215-233, http://dx.doi.org/10.1016/S0921-8009(99)00009-9.

[26]. Gardner, T. A., Côté, I. M., Gill, J. A., Grant, A. and Watkinson, A. R. (2005), HURRICANES AND CARIBBEAN CORAL REEFS: IMPACTS, RECOVERY PATTERNS, AND ROLE IN LONG-TERM DECLINE. Ecology, 86: 174-184. doi:10.1890/040141

[27]. Clements CS, Hay ME (2017) Size matters: Predator outbreaks threaten foundation species in small Marine Protected Areas. PLoS ONE 12(2): e0171569. doi:10.1371/journal.pone.0171569

[28]. Ray Berkelmans, Madeleine J.H van Oppen. (2006), The role of zooxanthellae in the thermal tolerance of corals: a 'nugget of hope' for coral reefs in an era of climate change. The Royal Society, DOI: 10.1098/rspb.2006.3567.

[29]. Bellwood, D. R., T. P. Hughes, C. Folke, and M. Nyström. 2004. Confronting the coral reef crisis. Nature 429:827-833.

[30]. Hughes, T. P., D. R. Bellwood, C. Folke, R. S. Steneck, and J. Wilson. 2005. New paradigms for supporting the resilience of marine ecosystems. Trends in Ecology and Evolution 20:380-386.

[31]. Knowlton, N. 2001. The future of coral reefs. Proceedings of the National Academy of Sciences, USA 98:5419-5425.

[32]. Brazeau, D. A., M. P. Lesser, and M. Slattery. 2013. Genetic structure in the coral, Montastraea cavernosa: assessing genetic differentiation among and within mesophotic reefs. PLoS One 8:e65845

[33]. Brown, B. E. 1997. Coral bleaching: causes and consequences. Coral Reefs 16:S129-S138.

[34]. Hoegh-Guldberg, O. 1999. Climate change, coral bleaching and the future of the world's coral reefs. Marine and Freshwater Research 50:839-866.

[35]. Kemp, D. W., X. Hernandez-Pech, R. Iglesias-Prieto, W. K. Fitt, and G. W. Schmidt. 2014. Community dynamics and physiology of Symbiodinium spp. before, during, and after a coral bleaching event. Limnology and Oceanography 59:788-797.

[36]. Walter C Jaap. Coral reef restoration. Ecological Engineering, Volume 15, Issues 3-4, July 2000, Pages 345-364 